electron microscope and its application in biology, with high-and low-angle X-rny diffraction both as applied to solids and solutions, besides various optical and spectroscopic methods, is impossible. A surprisingly balanced introduction to electron microscopy is achieved, but in the section dealing with X-ray diffraction the author tends to set and fall into traps cuused by over-brevity. There is not the space to distinguish between unit cell and Fourier transforms; it is misleading in relation to diffraction by helical structures to dismiss more complicated diffraction than that from a single helix by "Double and triple chain helices show simple variations of such (single helix) characteristics". Multiplo helix systems (for example, $\alpha$-helix, collagen) usually tako the form of coiled-coils and the relationships of their diffraction patterns to sirriple ones can be complex. Guinier's relationship is quoted for the determination of the radius of gyration of a particle from the X-ray scattering of solutions, but no indication is given of the angular range of its application. In a similar manner, in the chapter dealing with principles of molecular structure, I question the value of two pages on quantum mechanies. It is as if the author has tried for the understanding of his readers in the manifold "tricks of the trade" used in ultrastructure determination; I believe instead he should have given sufficient only for the reader to follow the arguments with detailed references to the specialized texts for the details.

'The book is successful in presenting biological phenomena as "pattorns of physical and chemical events organized in space and time". There are sections on proteins, nucleic acids, lipids, carbohydrates, the role of mineral salts and the role of ultrastructure in biology and medicine. In general the structural interpretations are up to date and embrace references until 1966. Occasionally over-brevity gives a slightly misleading impression; for example, the higher order low-angle meridional X-ray diffructions from all dry collagens do not fan out, and besides the order-disorder explanation of Bear for the fanning there is the fibril-shearing mechanism proposed by Tomlin and Ericson. Occasionally additional references would be valuable; for example, in connexion with the movement of a cilium or flagellum the author whets the appetite by remarking that plausible theories have been proposed for the control of the movement and its energy requirement, but gives no lead in following it up. There are a few misprints but none to deceive-I wonder whether the reference (page 105) to "Caltech" was intended, but perhaps today everyone knows what it means.

The section of the book dealing with the role of lipids is really a valuable review of the field to which Finean has himself contributed greatly. Isolated lipids, lipid interactions and natural lipoproteins are treated most comprehensively and this section merits the space it has been given-the same as the proteins, amino-acid sequences and complete structure determinations notwithstanding.

As a broad introduction to molecular biology and ultra. structure research I believe this book to be valuable both at the undergraduate lovel and espccially to the graduate physicist or chemist "converting" to molecular biology. I hope that in future editions the space now occupied by "methods" will be given to further structural detail.

R. E. BURGE

\section{GENETICS AND BEHAVIOUR}

\section{The Genetic Analysis of Behaviour}

By P. A. Parsons. (Methuen's Monographs on Biological Subjects.) Pp. viii + 174. (London: Methuen and Co., Ltd., 1967.) 30s.

As the author of this biological monograph points out, behavioural traits, when under some degree of genetic control, have a highly significant role in initiating evolutionary change. There is also a compelling urge for knowlodge in this field as regards our own species, despite the well recognized difficulties.

Much of the book is devoted to an exposition of how a quantitative behavioural trait can be analysed from a genetic point of view. This includes a scheme of analysis of variance for separating out genotypic and various environmental and interactional effects in a set of inbred strains for a series of environments; this has apparenlly not been carricd out before. There is also reference to recent attempts at "locating the polygenes", and chapter on the evolutionary consequences of variations in mating hehaviour. The behaviour that is discussed in greatest detail is that of Drosophila, the organism with which the author is most familiar. As he mentions, conclusions about mating preferences, the spoed with which mating is attempted and tho duration of copulation which are derived from laboratory studies may not apply in wild populations of Drosophila. Still less can findings about the extent and nature of the genetic control of such traits in Drosophila be extrapolated to man. Yet the difficulties of research with the fruit-fly and the methods that have been devised to overcome them suggest ideas for the genetic study of rodent behaviour, and in turn the andysis of rodent behaviour can be helpful to the human psychologist. While the anthor's approach to man through work on experimental organisms helps to highlight difficulties such as inadequate control of the environment, he also points out the advantages of the more sophisticated methods of biochemical, physiological and psycholugical investigation that can be applied in man.

When he comes to describe and discuss work on rodents and man, Professor Parsons has to rely more heavily on secondary sources, and he does not claim to be anything but extremely selective in his approach to behaviour in man. In some respects, such as the geneties of normal vision and ideas about the evolution of colour-blindness, knowledge may not bo as limited as he suspects. And despite the difficulties of making any sort of exact statement, there have been continuous attempts in the past few years to apply some of the principles described in the monograph. One thinks of heritabilities calculated for defined behavioural traits such as intelligence, extraversicn, drinking habits and schizophrenia, some of them based on natural "wild" populations, and of renewed efforts at assessing environmental variables by means of discordant twins, twins reared apart and fostered or adopted children. This merely shows the potential fruitfulness of a genetic approach in psychology.

The present monograph with its clear exposition of methcds, its awareness of the difficulties and its broadly based "attempt at applying evolutionary principles to behaviour" should serve as a useful introduction to its subject. James Shields

\section{UNRESPONSIVENESS}

\section{Natural and Acquired Immunologic Unresponsiveness}

By William O. Weigle. (Monographs in Microbiology.) Pp. $x+180$. (Cleveland and New York: The World Publishing Company, 1967.) \$8.

IMMUNOLOGICAL unresponsiveness can result from the contact of a potential antigen with the immature lymphoid cells of an animal in the perinatal period. The concept that this mechanism allows the development of a natural immunological tolerance to autologous body constituents was generatcd by the obscrvations of Owen on the chimaerism of dizygotic cattlo twins; by the speculations of Burnet and Fenncr, and by the experiments of Billing. ham, Brent and Medawar and of Hasek on the consequences of perinatal contact with transplantation antigens. Our undorstanding of tho cellular events underlying the induction of immunological unresponsiveness is still uncortain and the importance of the work of Dixon and his 